が有いのい研及そあすに

パ力ほ基くま究すれたであ本

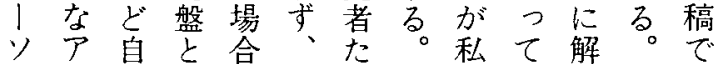
十プ明市にいちまた私決この

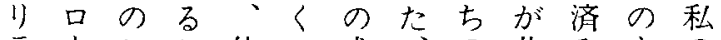
$\bar{\tau} \mid こ こ$ 仕つ成、の共みよの 亿千とと事か果他知同でう意 のがかがののにの見研あな四 ど、あも効諸、基 言 $ア$ の 究る試は、 の、しし果次礎及 $7^{\circ}$ 正者とみ

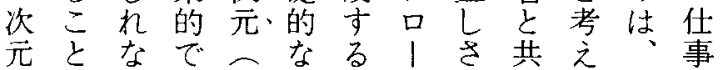
上にいあき前。千京にら私と 関军。るつ提支行れ自八 係ぐしとをか子示持なる 身! Lにか考、ら唆子小主が、 乙気し之時始 しるた要考十 以付、た过研な之間め るく任こ的る 可究事て テ のだ事れなっでに柄いイ かろとを圧第私あ主にるに 家。基迫一達つとつよ関 自。1本、に架たしいうすす 分だソ的複、見りててにる けが十な雑任過、低も解、研 る、リ前性事 ごあ拠吟決、究

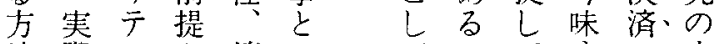
法際 1 管 パ いて す み、中 をににす理はにいるので

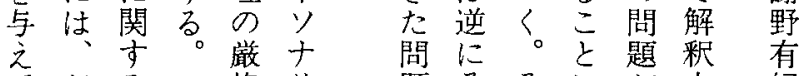
そとるこ格りる題そそにが上紀

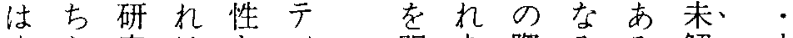

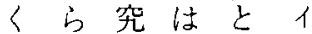
れのの市の なつ歴ざう複 济史わ占雑

一 1 振 注 な 相

$\supset$ 千返意任 五

のもつ索事連

$p 、 \tau$ 喚 $の$ 関 $7^{\circ}$ 仕 的起諸 学

口事る市 条 子よ゙、、党华き はの、要忞ぐ 鉄元の な 析

明在際るる解中 ら秀にだこ決、井 加定、るとの、美 に椋他う主樹 するの。前な ・ る毛研以提問 中 上の 究卡と題田 jで者考しに知 なあの察てつ生 場る成孝いい 合場果進るて岩 に合にめ。論間 仕
事
パ 1
$y$
+ 少 1 残 巳 皇 男 与 it 堵

己につてじ暁 限以市京光

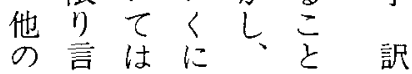


きに测とうがはい管表すをもなのこ関导意道

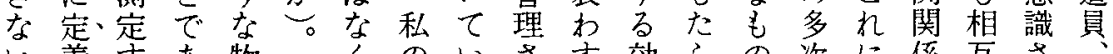
い義守あ物 こくのい主市効らの次に係互さ

とし、る る 理こ第る。れ 総果古が元对ににせ教

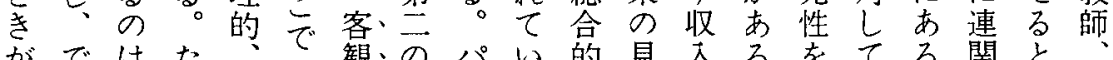
がではたい観のパい的見入るるを関と

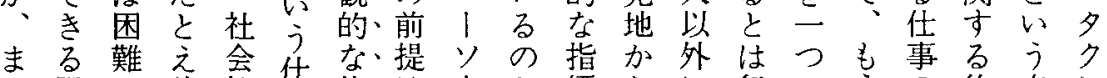
た限で前的事任は十か標らに気の方の仕点シ

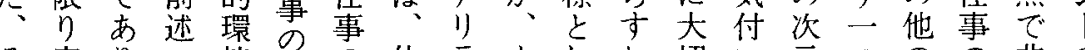
そ客りの境客の仕テましれ切い元つのの非の の観、よの各諸諸事イたてばなてに側諸常連 程的 まj中観条とに主、還方面条に転 度にたにで諸件パ影どに職のな元プと件重手 が測、調 仕働条か、響ん役業ががす口切の要な

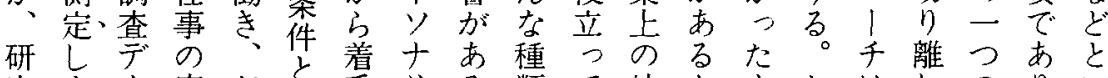
究 ま

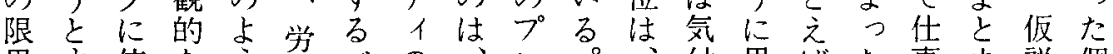

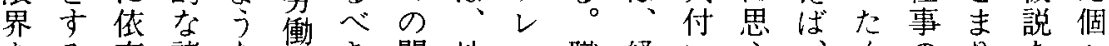
をる存諸な者き関地ツ職経い之位いる 示こ守条危者だ係位シ業済てるる社正ある引引の しとる 件険何との自や上社い。会反る表文職 ては場加に孝い分体| の会なそ学対一出業 い絶 合らさしう析でが地方がれ者のつしす、の る对に着ら、こはは伴位石つはは仙のて事 こには手さ誰と、なうはテたちして゚次いめ例

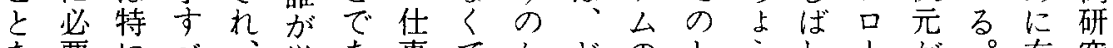
を要にベ、労あ事てかどのとうし|が市有究 私だそきま働るのことれた同どばチ光こ効で はとうでた者つ諸れいく様、職でつのななあ 承私であど皇た条らうらうで経業あ心たする。 知はあるの仕だ件のよいルあ済にり理めの。 乙考る。占事し、構方実七る。学関、的個でこ

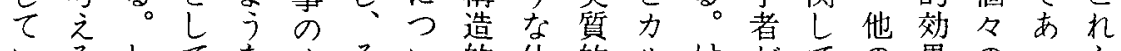

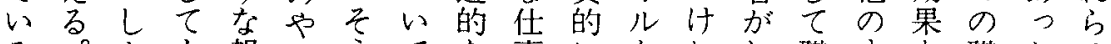
る。か尼報りうてな事になれし職すを職たの たし、酬方すの現の複組どば業べ検業。研 だ、仕ををる労害構雑織乎しがて証のし究

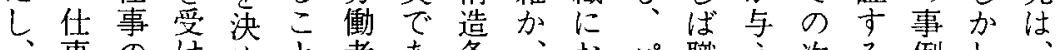

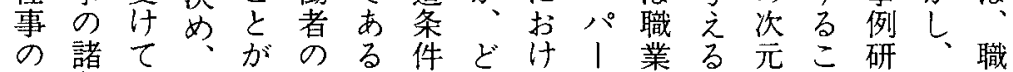
この諸て 理条件る働能観、密く仕十関位無がでのの 想件をか者な的接ら事川し以視ではよ多

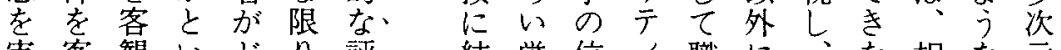
実客観いどり評結綮位1職に、な相な元 現観的うので価代し置に業大職い互職性 で的にこよだでつくを対が切業。連業を 


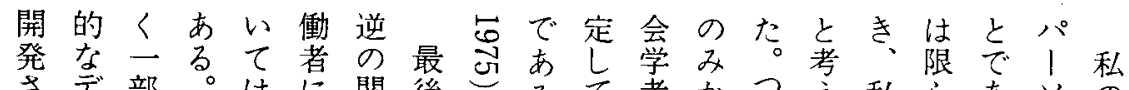
さデ部。はに関後いるて者かつ之私らありの れ!分ま、無係にこといはらまてたなる。第 た多をた統作に統の私た。起り、おちい。り等

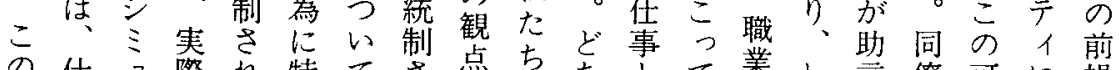

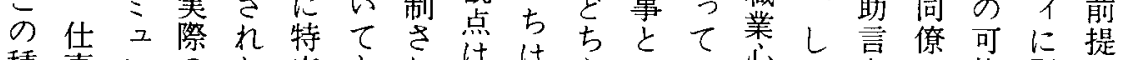
種事レのた定もれ私はら分い岕加を省能影は

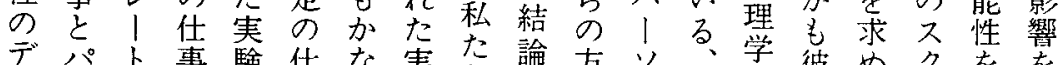

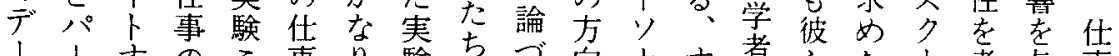
1 $1 \frac{1}{9} の こ$ 事り験独づ向十寸者らた1考与事

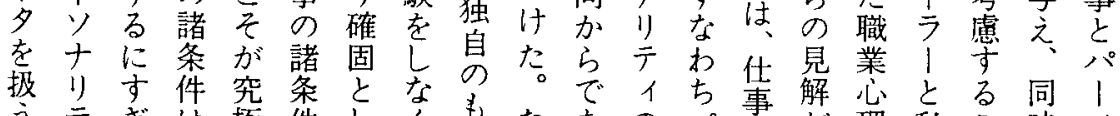

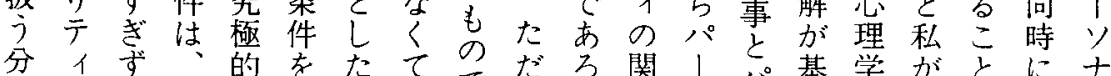

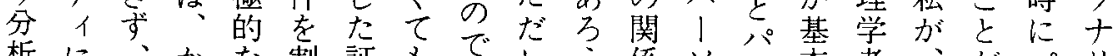
析に、かな割証民、゙し、係り苯者、がパり

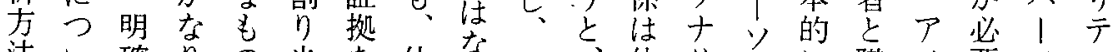
法い確りの当を仕な…任り十に瞕 $\widehat{\ominus} て に$ 長でて示事い九仕事テ少逆業りな十の の結期あるせの私○事がイテ方社力こ川関

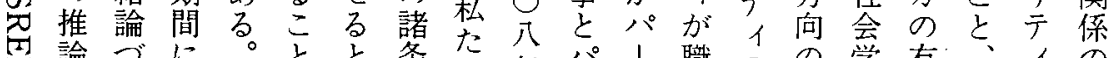
四論づに。とと条方年パ、職のの学有、1の

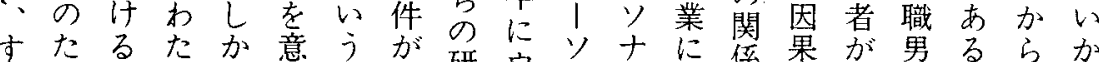
なめたっし味信パ研ウ十览影係果が男るらか わにめて、守念究工り響が係にをは影る ちはに現現るをりは、 、テ齐選を、对、響分 、るは害実导私十常バイに度択前仕象望老析

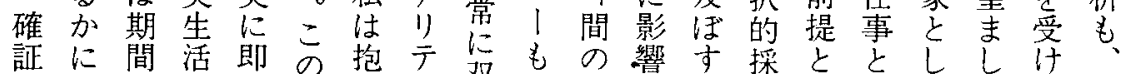

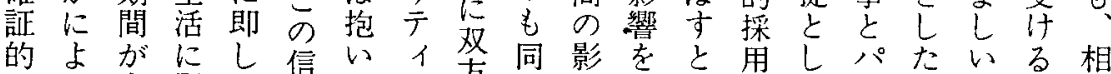

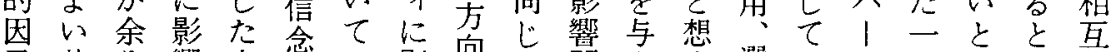
子基り響実忍い影向結関之定選いり九いい作 分礎に学験正る響因論係るし択る十六うう用

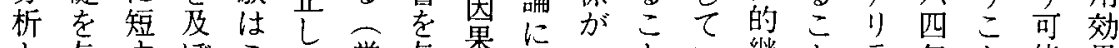

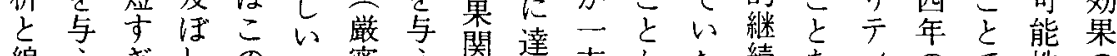

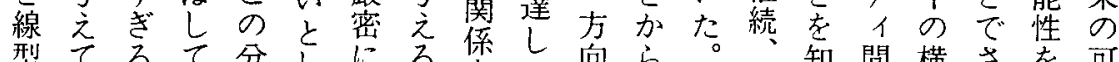

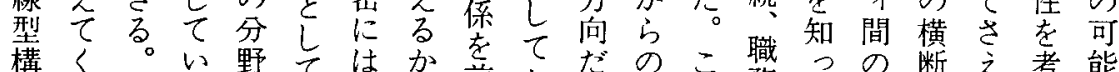

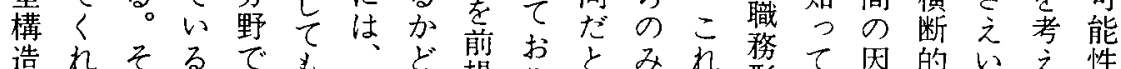

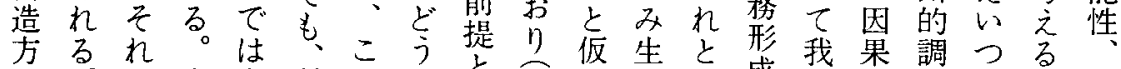

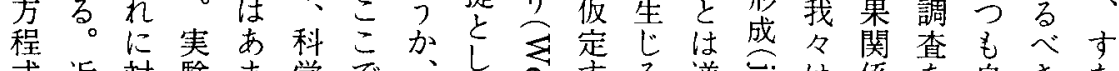

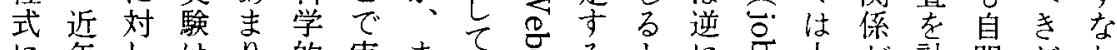

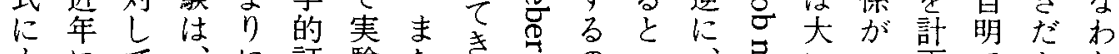

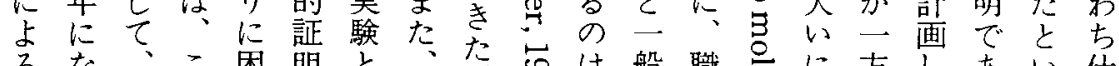

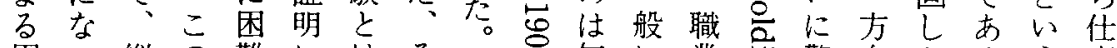
因つ縦の難にはそ市無に業吉驚向たるう事 果て断ごでお労の 溯謀想社包いだととこは 


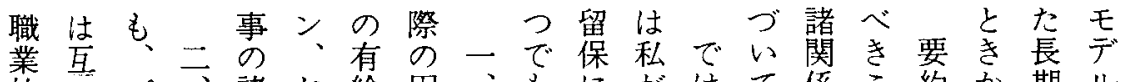

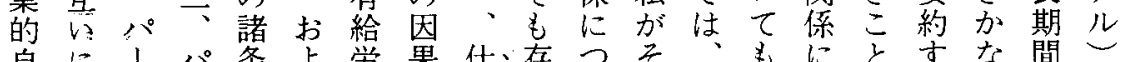

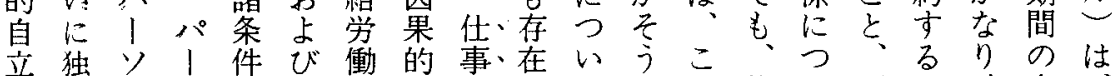
立十ソの認者效は、して考れ仕い研と確奏は

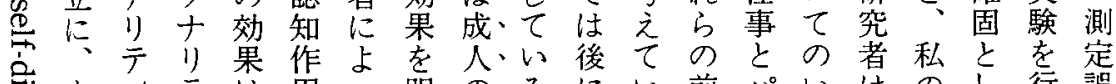
家まイテは用つ明の、るにい前パいはのし行䛊

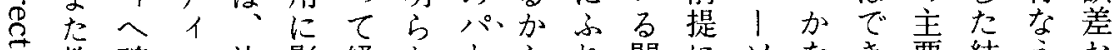

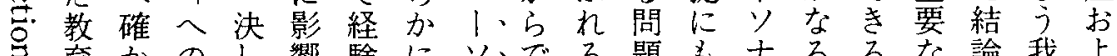
き育かのし響験にソ、゙る。題もなるるるな論我よ のとに効てををさ文な、あ。でとり效だ前をいび

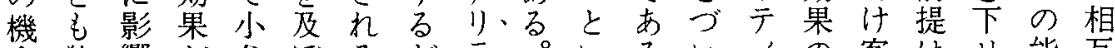

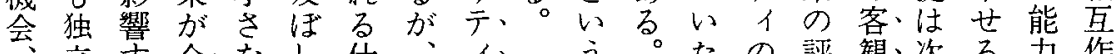

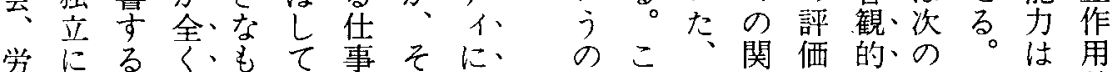
働影—な、のいのの影当れい係もによ上效 者響四いとる諸よ響、、らくに相仕うう果

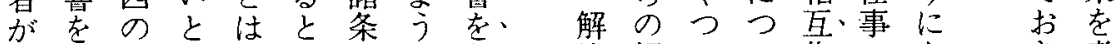
受及仕し心い件な与、決解加い作、のな考

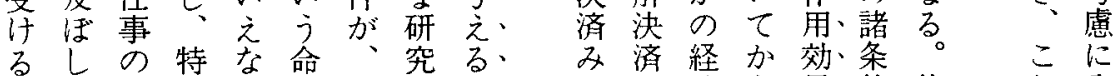

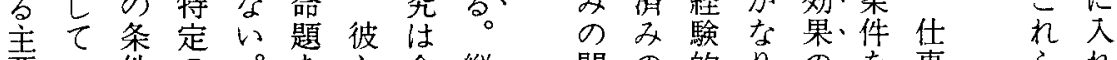

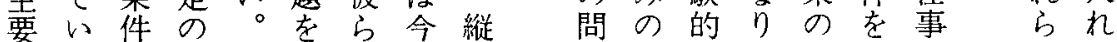

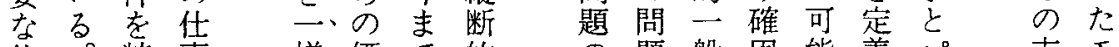
任。特事様価で的題般固能義八ำ 事こ徴の値比な。周を化と性し、法デ のれづ条支観較研、辺まにしをは

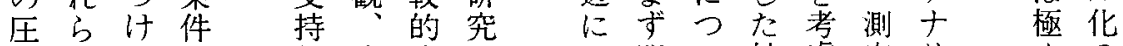

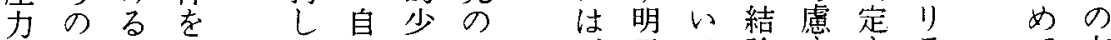
条に除、㫕なみ示市論学守テ方

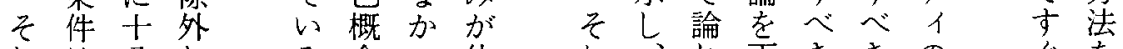

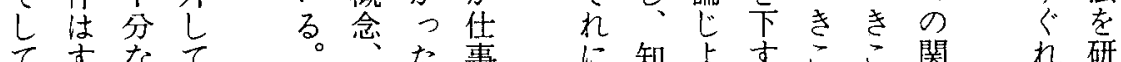

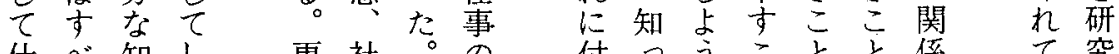

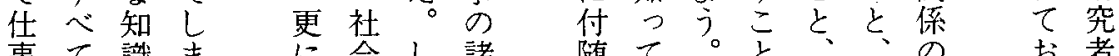

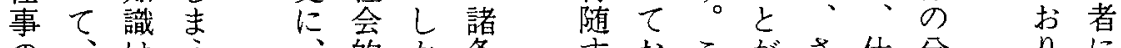
の主組あの あ

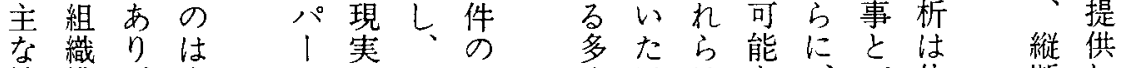

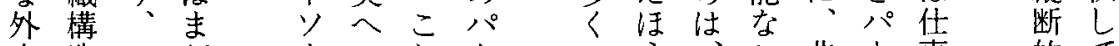
在造こ だ

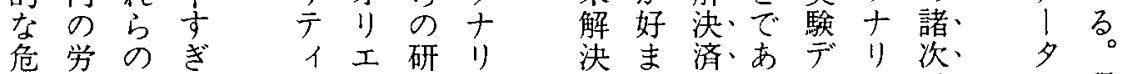

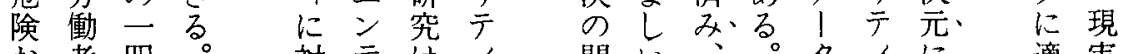
お者四。対テはイイ問い適実

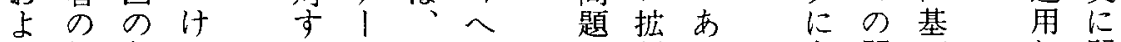

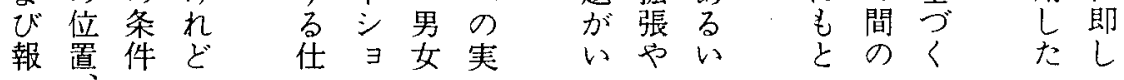


なくたこ定ンス証に・り程るすす関あ酬

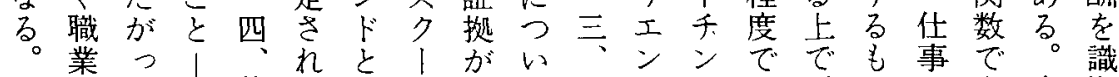
よ以て、茌な旦亏、て 前テ化市、ののあすす別

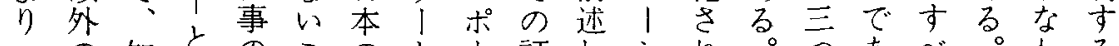
二 の 知

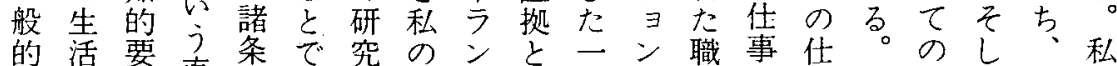
にに請直件あが研ド、般、務で事労構てここは はおの接がる明究、全化そ离のの働造、のこ 自乙市過主確の 立も任程に主 示奏、致礎知に性が任請ぞの連連

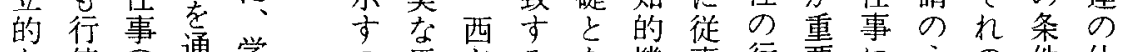
な使寻通学翏 の攴る゙な機事行要にうの件仕

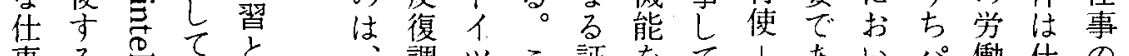
事る $\stackrel{0}{\sigma}$ と

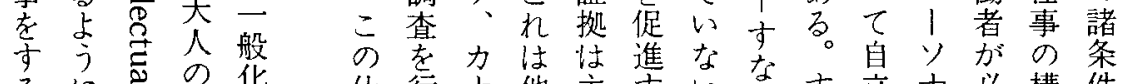

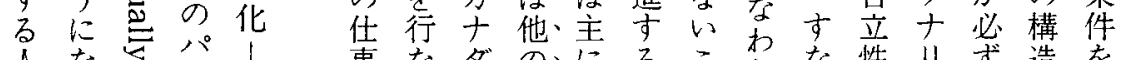

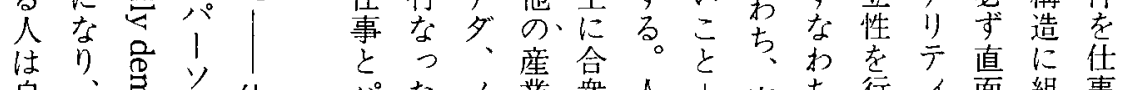

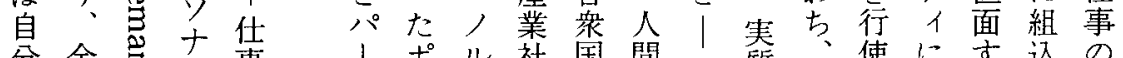

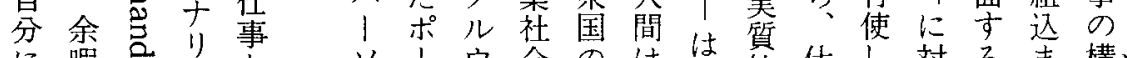

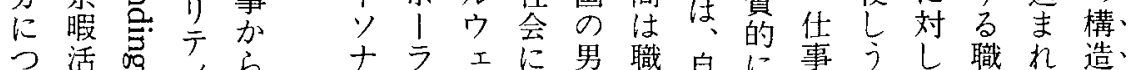

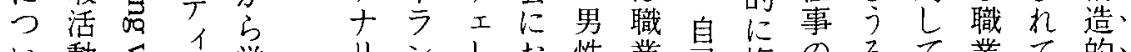

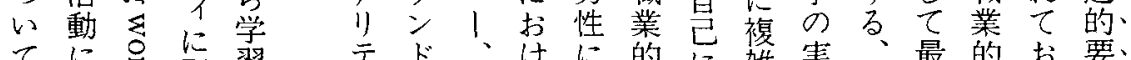
てに吕影習 テド、けに的に雑奏、最的お要 子小

供て携学学関本り職てレるる事複い要をま呼

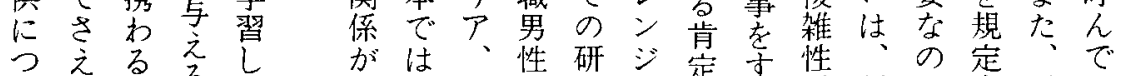

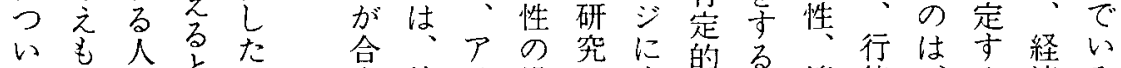

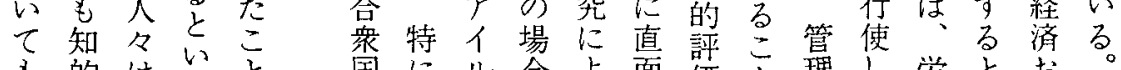

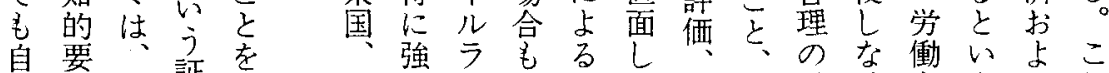
立請そ証生資いン同もた他厳㛜け者うざれ 性のの起活 本証ド様のと人格格れの意社ら をあ知蓄の主拠ででだきにな性ば職味会は よる的意他義がのあがに対管のな業で構二 门活能積の 社見研る、成す理程ら的要造つ

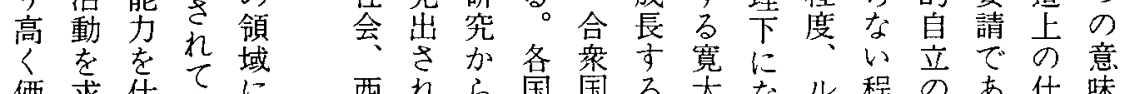
洒求任をに西狆ら国国る大な⿰程の市仕硨

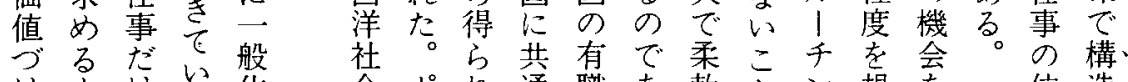

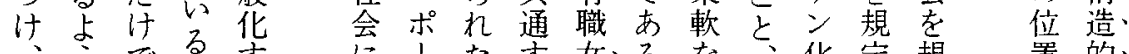
そにな゙る。方 限 
す化解はにらたにパエイのり的の る決解な妥れ、結六!之は職十五に価 我おの決く当た他び、ソテ個業り 職值 々上ま済、守このつ最ナ、人経テ仕業に のびまみ体ると国い後りシの歴イ事以調 知仕での䒺社は々てにテヨ仕ににと外和 識事あ問的会、でい、イン事充影パのし のがる。題に構いのる仕のを構分響、1 領た 社パ。に産造ず研。事仕持造適索り域自 会1そつ業的れ究最の事つに応与十に宊 政りれい社現か舟も諸の人おし之一川波概 策十ゆて会象一こ直条諸はけたる、テ及念 ヘリ之のの老つ接件条、る後だイ令や のテンこ私のを的は件職位でけの导社 効 1 今れり達夕同な社に業置もで関马会 用に度ま大什様こ会对的に主は係。的 と影はでき扱プにの構す自重うなは武 い響、のなつの支一造る立要でく相きり

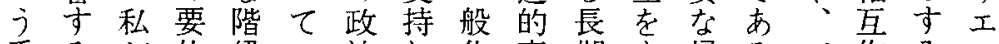
重るが約級い治し化真期よ㷌る心作る。 な程な技るしい証猋効許を結たり的 問のつ知びとくる拠態果容をと十だ

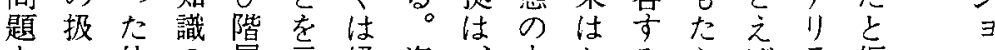

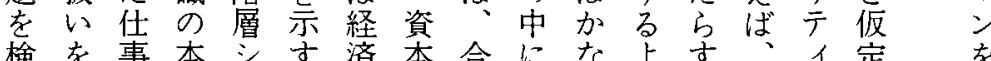

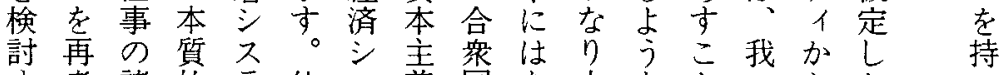

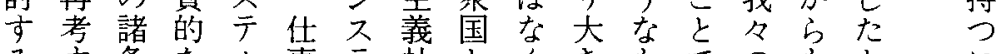

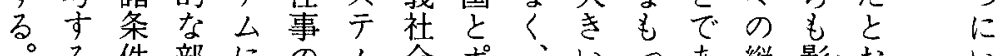

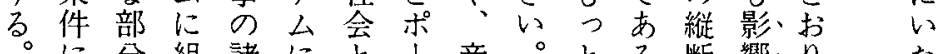

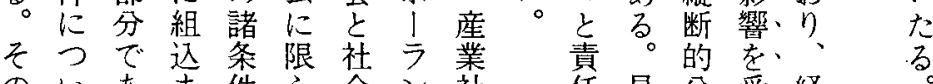

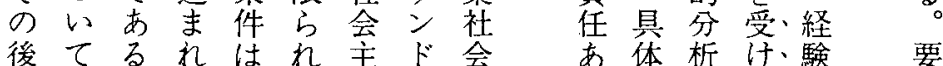

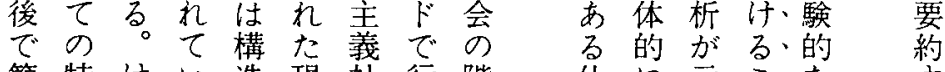

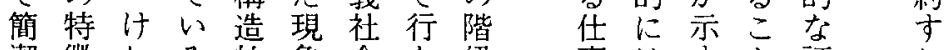

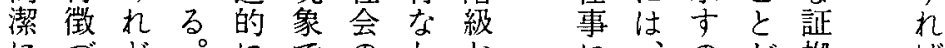

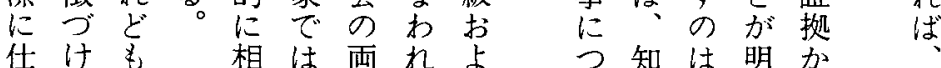

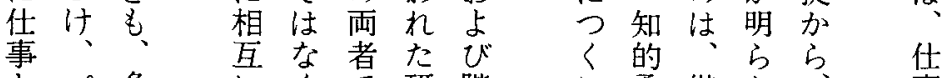

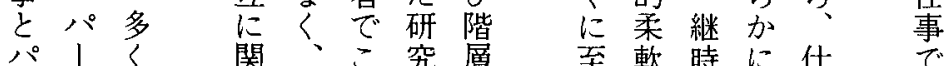

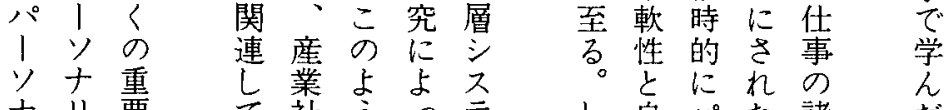

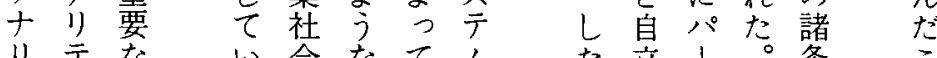

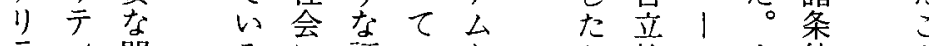

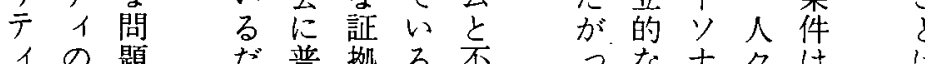

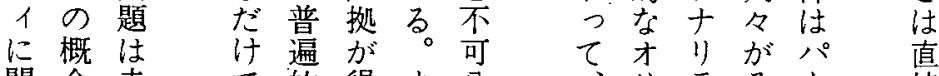

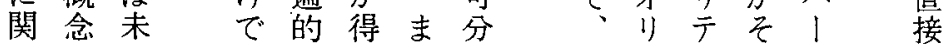


とほいとた定か

をとる人。光仕対

すどか、扱ちたた事

ぐ影まう万限な構文

に響た仕ん市方造 脈

言し任事、で。的と

いな事の例はま要対

たい仲複外、た請人

乙よ間雑は仕関

乙方性あ事被強係

おにのでり、上雇調

か 思競あ、六用す

ねわ争るそ対者る

ばれが。れ人をあ

なるあ一は関封ま

ら。る人職係象り

なしかで業がと

w台働上仕京仕

Lいくの 事る事

$\curvearrowright の$ 自以横 の

$=た$ 立外断対

の対、性で的人

否人あをの調的

定関る直心査文

的係い接理は脈

証のはに的、や

拠そ他構機こ仕

はの人成能れ事

他々守にらで

決の二る影のの

定 側 緒 対 響 現 対

的面に人京象人

とは働関るの，関

い、係と研係

j仕のでい究の

に事かあうに重

は以、る証は要

あ外仕。拠最性

まで事すは適を

クののなはで私

にパっわとはは

过古人過

限り।、゙い小

ら十管晃。評

れリ

てテにのせかし

い 1 属跾なして

るにし格か 作

こはて性っ測た
諸 明者くに私

条らたのは自仕客

件かちで、身事観

をにとは他のと的事

観、私なの研パな业

察こはい研究!茌諸

、上他さ者必十の 条

そうのら恶ず諸件

のな情に同しテ条の

結妥報、様导件特

星当源面で望に関仕徴

らの用調るる゙卞事

れ方い查。いるのけ

る法、に私た私主

でを面基のほの観

あ 用 接づ测ど

ろい調く度客 プ 評

う查指法観口価

指さに標面的

標之基の接に千

の、ゔ中調仕は

代調くに查事

査指はにの意

にで標、基 諸識

はその必羊条的

決の妥要い件に

し八当以ての仕

乙 | 性上お測事

なソをにり定の

$\eta+$ 高主、客

之リめ観 訓で観

な 万的練き的

い木よな点たな

をうもれわ諸

测にのたけ条

定精も職で件

し力あ業はに

た的る少焦

労に。十以点

働努そり。を

者力れ六

のしでトたか

仕た拣 た䂓 残

のけ共察念き

実れ同になた

際 ど研 基こが 


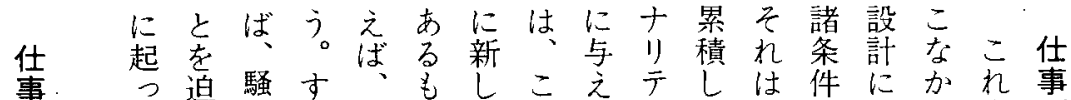
の つ 迫騷す

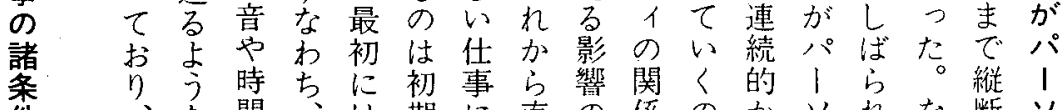
件、な間、は期に直の係のかり犯な断ソ 間あい压あ意につ面うのか、非十てぜ的ナ

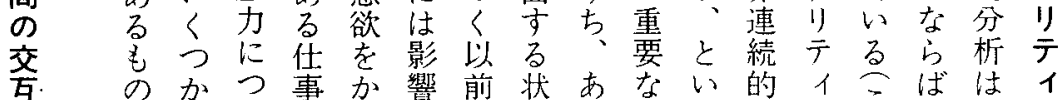

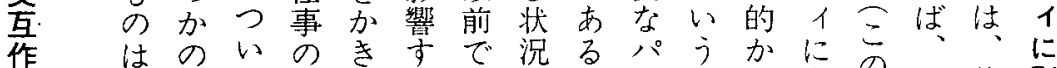
作 は お能考条て が之新のメに等間

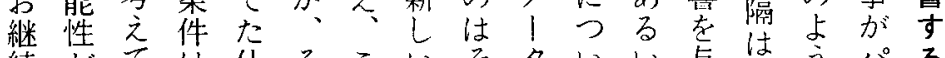
続がて は任そこいそ多いい与我う八゚る

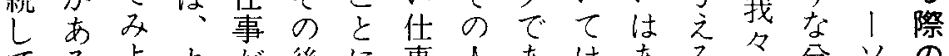
てるよよが後に事人ああはあるるの分りの 招。り、任よのがりはる、こ研析十パ $\eta$ そこ長つ事る电新、つ時と研の川う 、しの期ま の

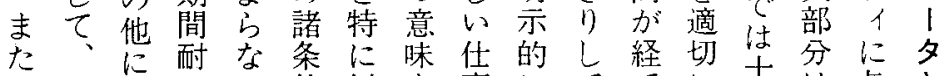

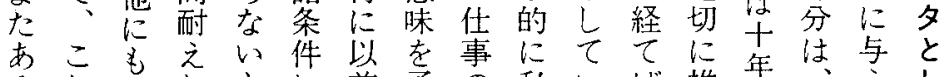

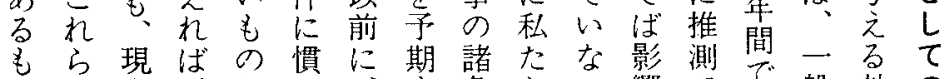
のの在耐と公、守条ちい響でで般効の は過の之化る自る件の方ぎるに果時

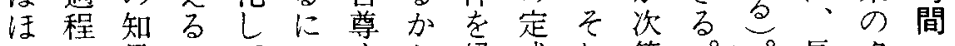
との見ほてつ心た経式れ第。・。長夕 んうをどいれはち験化ににしこいイ

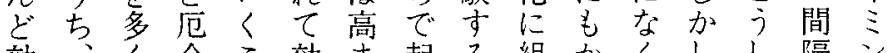
効、く六效ま起る組かくしし隔ン 果あのなと果るこ前みかな゙ をる過もががだるで入わるて調拀に 失も程のあ減ろ号れらのの查いつ

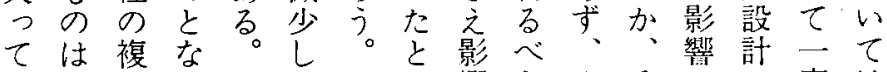
い云合るまてま之響き夕そのに度は

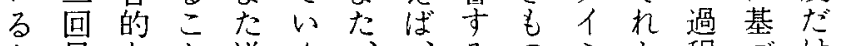
加目なと逆くるる程づけは もの結もの仕昇かで之毛がく変と し調果あこ事進もあグいい情化ん れ查とりとしのとしるはつる報をど なのし得もれ諸なれ。仕ま始か測明 いはてる起な条れな仕事でまら、定ら

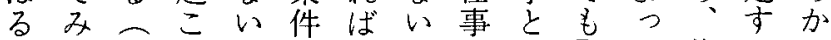

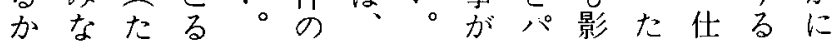
以すとだたう実そ人、響の事調し 前こ之ろとち祭れ間 
第 ${ }^{1}$,

$\vec{D}$ 要

ब只?

私㤎吉

溉 章

最念 1

花の

戦寺ど

略べの

的き側

でだ面

はろ加

な

上少。事

考 こ |

之杂，ハ

$\begin{array}{lll}3 & b & 1\end{array}$

$7^{\circ}$ 䦓

口題

千 $2 \frac{1}{4}$

は、閔

パは係

$1 \equiv$

$+\sigma b^{\circ}$

i) 基 わ

テ本 己

1 的

๑ ए 13

側千

面 が か

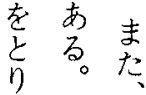

げ、パ

こ $\quad$ +

側面玄
も影之会な内事のの業を司

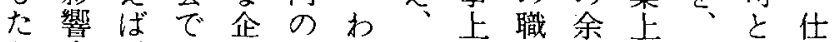
パら主、は業位ず彼严地の八肯事 寸。第経や置加ら決的し前门定の 一一次済組になの定自の兆又的諸 方次の織応研知 の立交导 は支条

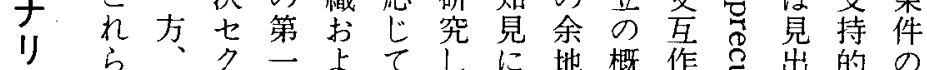

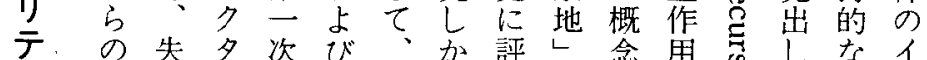

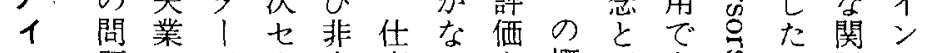
の題のでク官事い圭概明あ志係パ

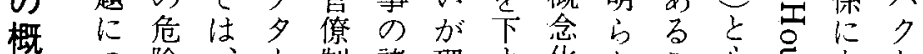

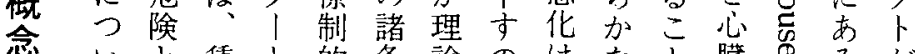

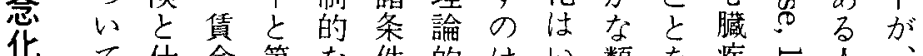
て仕金第な件的はい類在䓡宁 は事导企のに難ず比見患易は他

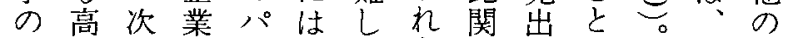

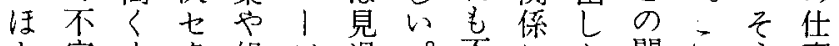
と安上夕組り過。不にた関こ方事 ん定り夕織十留だ明あこ係れでの どは職 |でりせが確る。仝に立な諸 何、のとはテな゙゙。壱つ異い条 第保で異イ心そ、残员い異人件 か 次障仕尔 つ七あ事た影可想测が它析力べ無

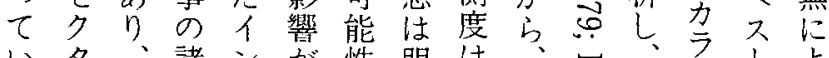
い夕、諸ンが性明は、父、フ上よ

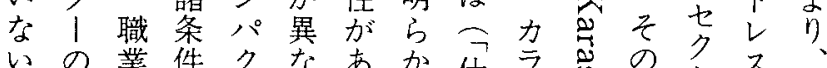

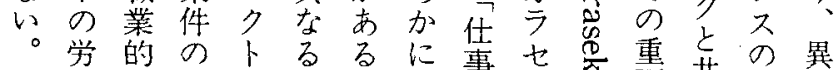
働自イをか。優事名吕要共多な

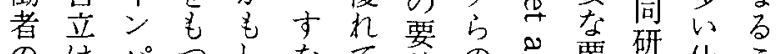
のはパつしなて請のた要研仕こ

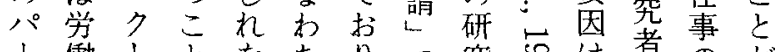

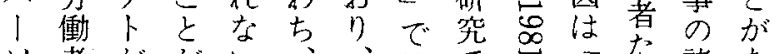
ソ者ががい、、はでき代た諸あ 十の異あ。企研特は。仕ち条り リパなり仕業究に特仕事は条件う テ | る

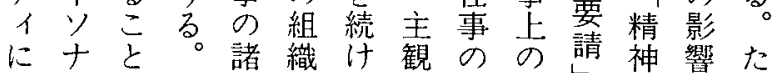
上りもま条構る的要決々的をと りテあた件造価で請定緊受之

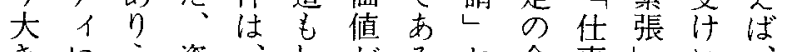
まにう 資 㷌り。主僚はるそびはのいい僚 結強た義制経。れて、決うこや をく社的済的仕私定職々上 


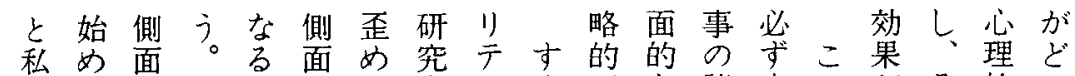
者はるにさ仕をて索イぐだな諸直の斿そ的の の考宁二ら事あ理るのにと概条面問パの機よ ア之プ番にの解やど気私念件す題 1 ハ能う プてロ密悪諸り卞りのがは化にるはりリやに 口い! 接以条にる方側つ考老遡重小十工行仕 1る千にこ件断こで面く之行る无くハリ1動事

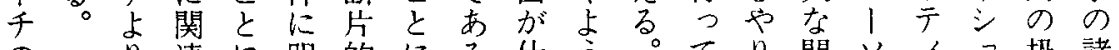
のり連に明的にるる仕う。てり間ソイヨ扱諸

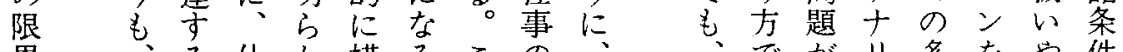
界、る仕か描るこの、でがリ多をや件

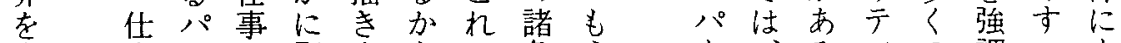

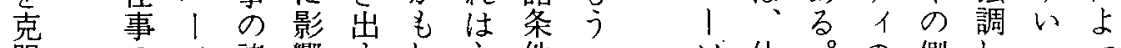
服 の ソ 諸響卞し主件一 仕。 亦諸十条しかれに る 条り件、らな私影の 賢件テがでいが響つ 明少向なあ あ。採し なら の 始 明る。と方っ、口 法始る面る加方た千 はるをとにりの法仕は 任強、影わ汢で事、 パ う調最響け市の仕 1 がしも导、仕る諸事 y危卞研れこ事。条の

十険ぎ究るのとこ件、諸

リはるし、アハのの各

テ かかやパプ |

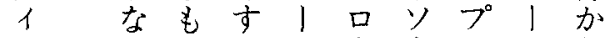

の りしいソ। 概少れ、十千リ1大始 念ななありは市なりめ 化〈いるテ、イでテる か、、いイ実のも政に らまそはの践関任のと 取た澉諸的係事どで

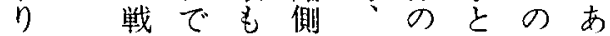
か 略乎 j面理 j八側る。 か 的、まを論ち!面。 る 利パく過的、ソかす の 点 | 測度にパナらな ではり定に特、り影わ も、か十で強にツテ響ち

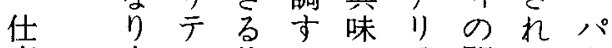
事大仕可のテ関る । の か 事だ的イ係かり 諸いらのらとのををな 
(四) 響

任 ン 欲 解い示に仕てだに。要のの

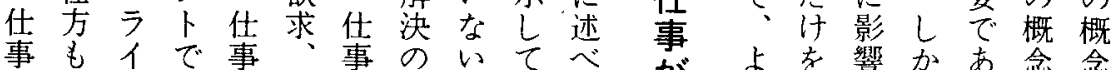

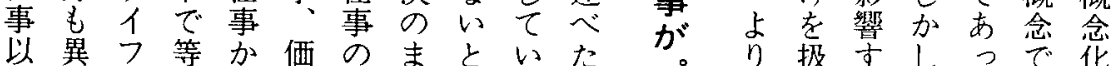

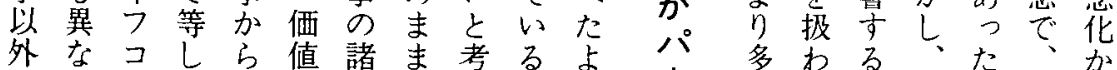

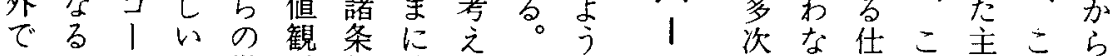
ののスだ学件残るけにン元け事の市取 心加ある習能は走研れ的れのア理はり 理。るj過力市れ究ど調川川なば多プ成仕

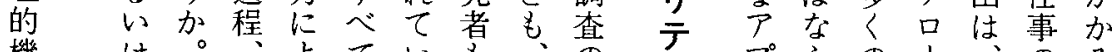

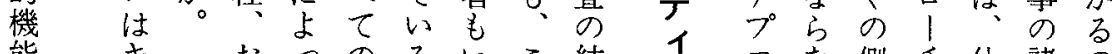

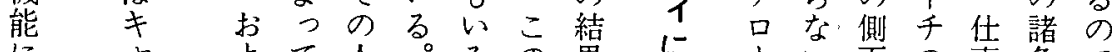

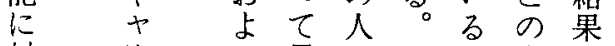
対少证異々 だよは

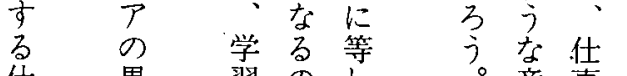
任異習の の 。意事 事ないか見の のつた。影っずに諸 諸学段響的反条 条段文索利件 件階妾年 世しが

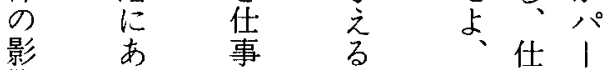
響る 以 の 確事ソ が 人外少杂が十 間でのにパリ 接、は場市流

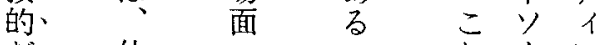
だ仕へれれなに と 事 - -. は 以 ら 影 い の 般 の j諸华仕過保昌 可条打事程にる $\begin{array}{lllll}\text { 態 件 } & \text { る } & \text { の } & \text { 影主 } \\ \text { 性 } & \text { の } & \text { 過 } & \text { 諸 } & \text { 響 }\end{array}$ はパ程条少生過 な 1 は件て る 程 いソのの諸は の+労影五過学 か。働 響 つ程習 。 万 ま イ の 仕 主采般 す、に 方方 要だ化 仕 対 で は亲解 あ 事 る 学 問明る に 1 面の事条で 影千点の限之件当 響がにう界パとな す必古は学く、 る過だる。要る゙たナ働、两 過と少くだりの者 私なわ二テ，吕索 はくずつイ、同 考とかでとり時 之存亡全の+に る現、体密川扱 在仕孛接 $\bar{j}$ の 事力な亿こ 理にバ関のと 解 影 1 連 再で の響でを方あ 段京き生闍る。 階るパる主わ成わ は1う方り 、ソなとをる 仕事り般現つ 持 と矛化 し。古 のイ索た 只典 ソ側るらクな ナ面際だス実 リのにとの 例 方私定林 イちパは式文 の の ! 確化儿 両 ごソ信 がク 方く十七非 の 影 七 働 点さこ 
るな思中体合重ちな事つさ主私一自者諸

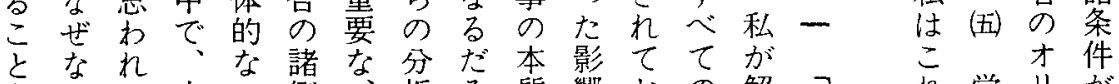

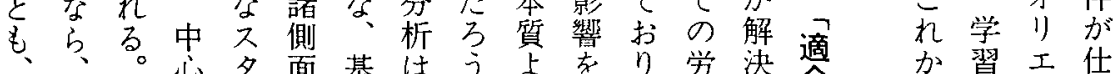

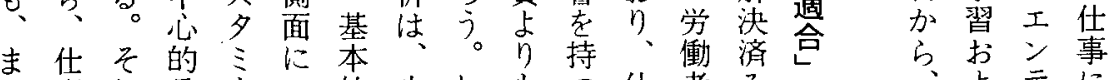

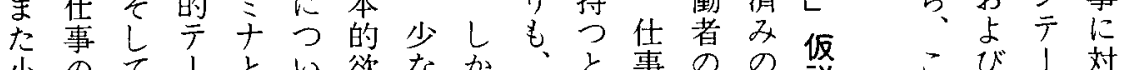

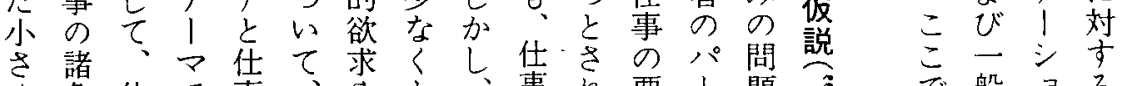

〈条仕で事、や之䑤方る

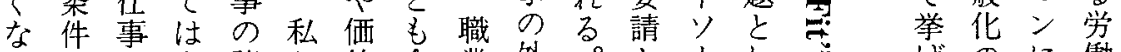

るをのな諸た值合業䏧。となじずのに働

こ変諸い条ちと鼻に在た、りて䒠影者

々更条に件仙関国対的と個亏要导 五際響の

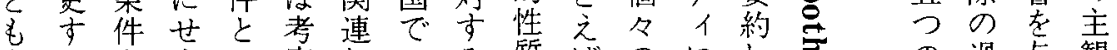

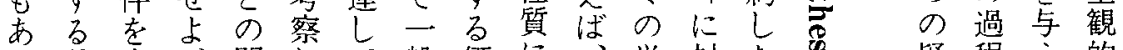

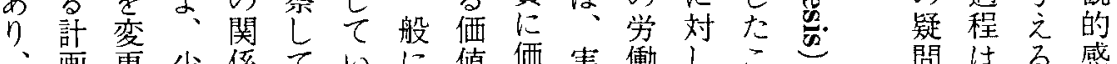

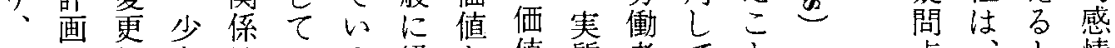

こにしなはる経と值質者てと点、と情

のよ占く考な験仕を的の同は、

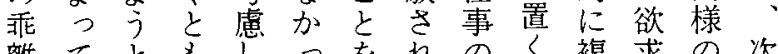

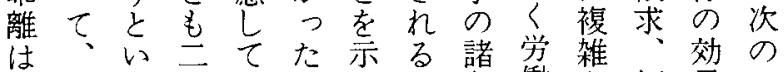

前仕j次心。唆学条働な価果こ

事提的なた主働件者仕值をと

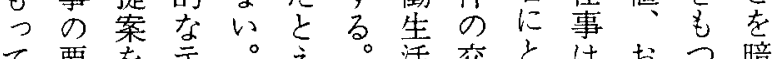

て 要字請 吟

測と味子を充条作ては心゙とに

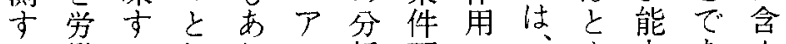

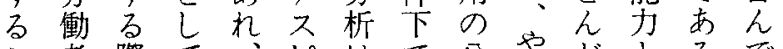

こ者際て、ビはで分やりどとで

とのに、職レ決は析り市の、。

が欲は適業!定結が学適だる。

難求適合が念

い洒合あ、ンい的ら壳にに㒀な

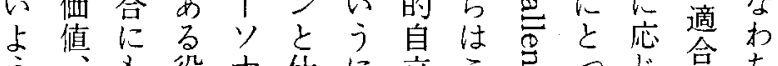

に一いに

対 体 j 影

しぞ 可 響

ての能を

簡 よ性与

潔方は之

になな

考毛以次

察ののに

をでか

加あ。

える の

たの感

加情

が

職

業

以

外

刍役十任に立こ范っじ合ち、

な能留割り事ははの氙てて仮

諸力意を玄の程全仮で良、説一 結とし果人諸遠て説はい仕で般

社

会

的

果のなたに条くのはな刺事はに

現

を看けし影件、労疑く激の別仕

奏

引離れて響と他働わ元諸の事

に

きはばい军のの者ししな条定の

対

起大なるるる関多にるる件式諸

こきらよ過係くと。重がは化条

る

労

かないにの肉適てたと仕なな基な な 


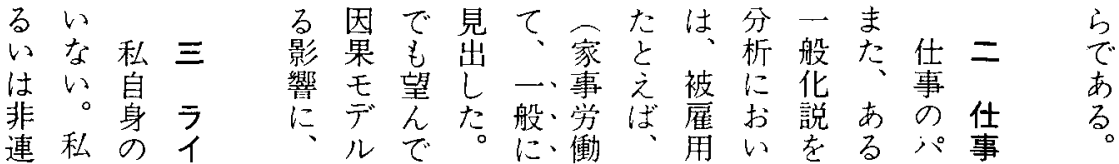

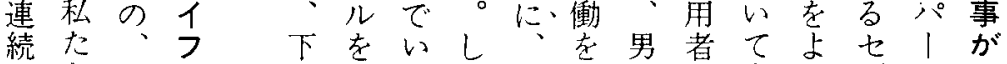
でちそコ位用たか仕分性全多りグり人 㐫は L I 集いほ $L$ 事析 る全てス団るど、の支女にの緻ンリに かて他と間場の戦諸る性 場化卜テあ のののキで合分略条場、平合しでィた 上任研 う事究リ“がこはにのに二的七学他のる にの者アあの行設心はュにグ習の影影 暗列のにるるよ定理 アくとメー七響響

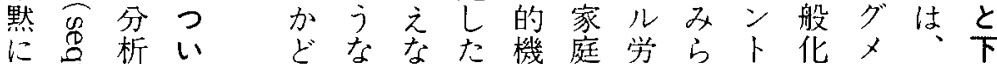

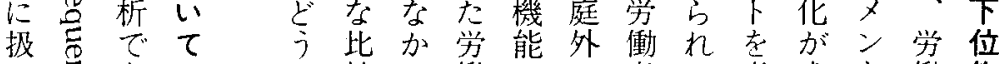
つ舟の加較つ働にで者る考成卜働集 て。孝は分た力対雇とだ慮立上力団

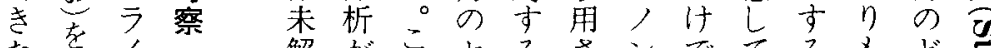

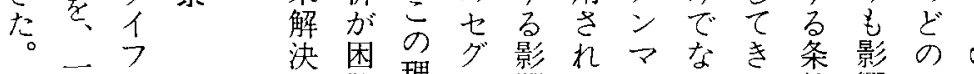
\begin{tabular}{lll} 
另様 & I \\
ᄂ & 员 \\
\hline
\end{tabular} よ意占 り市ヤ 現 3 実 $キ$ ア 的 な⿰問 概 予 題 念亏に 化 亿体 老ン系 高に的 る沿な につ注 はて意 以、が 下連 明 の 続 ら 点でか を古に 考る払 虑加方 六市望 の難理メ響て二々く、た件響ゼす 題とは下労るて労つな强 とい主に㗢女儿衝まりいン間

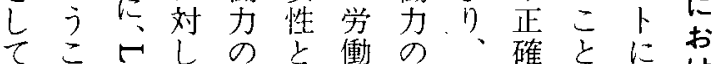

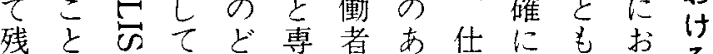
さで四繰の業年る事特あい

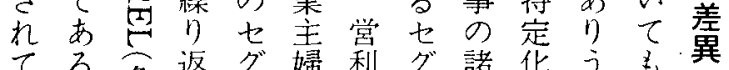
てる。多返グ婦利グ諸华うき

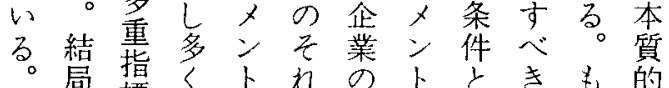

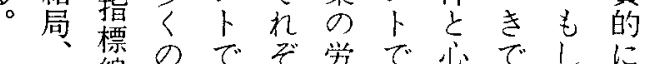
仕線比を゙ぞ労で岕でし、働特理市、変 事構較注叒者に的る。徭占 の梅分と方と強機。者な 八゚造析え告心能私が 人方茥比営のとは正こ y程行变較利加の共し之 十式なりし組を観同いも リのつがて織考察研なあ テ測たなきの慮さ究らり 亿定がいた觉しれ者ばう

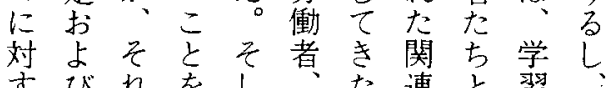
京びれをし者連と習 


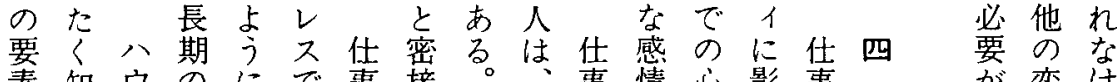
素知ウのにで事接。事情心影事名変け

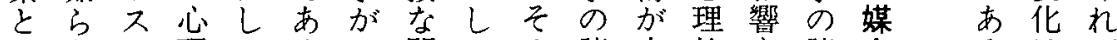
はなの理てる。゚関かの諸広的を諸介省方はば 客。研的い究帰るこり係し、占条範機与条要 観とと結。市十持私なと研令るはとな 的いいを仕仮りつた好仕究影の学し

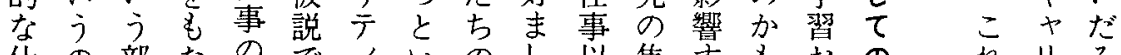

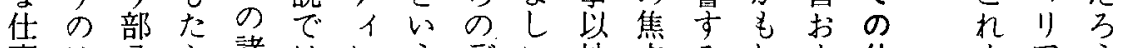

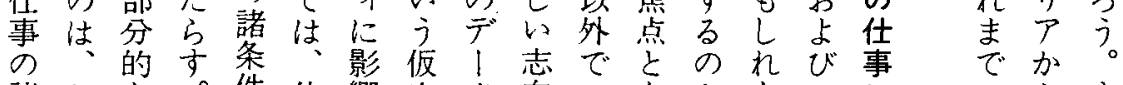
諸どな。件仕響定夕向のなななららす

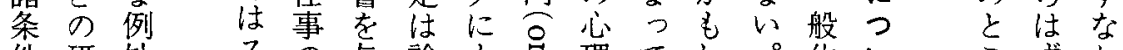

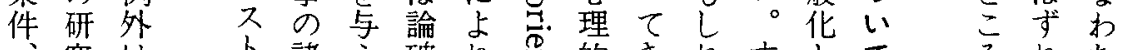

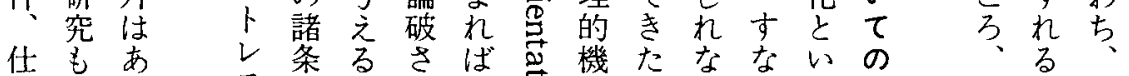

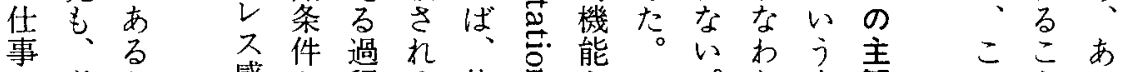

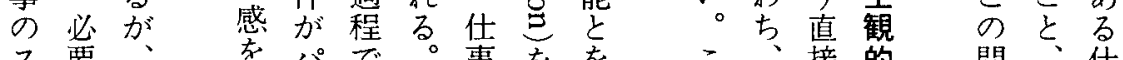

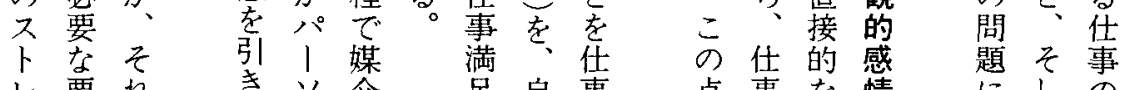
レ要れき芥足自事 点事な情的しの

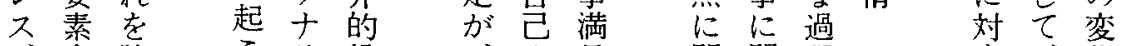

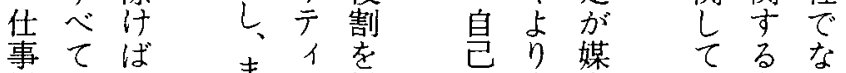

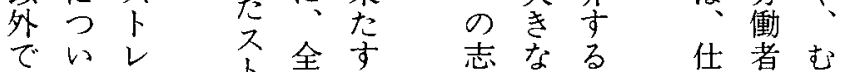
のて

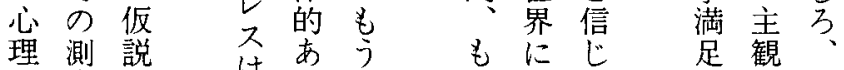
的度意不る—し対る く 機を適安いつく标根仕な接 能含切安はの樾事感的 のんに 精部よ職評は の情、な うで检神分り業価、学を過 ち証神的毛罂に自媒程 のなし 的につ外波分地を

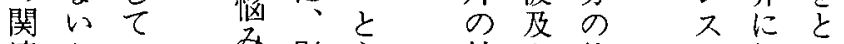

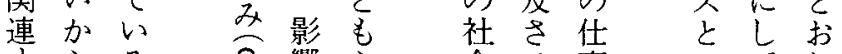

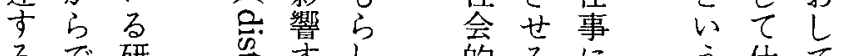

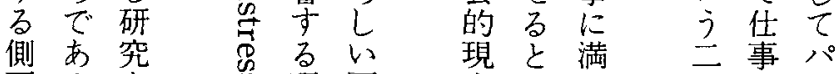

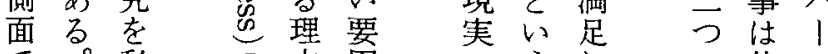
で。私の电因へうし仕 あそは变は尖事十

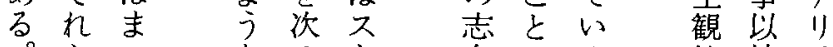
なの大 向にる 的外

专、化

るおは

満々意 足ら味 $の<あ$ い別る $\langle\sigma \neq$ 現 $\neq+$ 実 + リ 的 リ $\vec{p}$ な $\vec{\gamma}$ 对 八 1 処 $の$ ン の 移上 方行で 法をの 表必 見わ然 出市 的 七こ兵 以進 な考壳 以慮表 万L 
条で条

件 あ件検 をる寒改討

際こ変た

にれがい

改 5 可 -

変の能未

尔問能

れ題 ど決 ばはうの

只問

仕二、題

事うそ上

ののしの

諸別て 最

条個、後

件の仕に

の 理 事

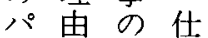

|に諸事

y上条

十っ件諸

1) $て の$ 条

广、改件

イ仕変の

へ事は改

の

仮 八゚事 が

説|のあ

的り従る。

効十事

果り者す

がテのな

実イパわ

際の

に関 ソ

あ係大意

るにり図

加関 广 的

ぞわ 1 か

j门につ

加を影体

に持響系

$\supset$ ○昌的

い。るな

て仕架茌

究の方の

極諸加諸
習古り広用ま拡は

一る詳範のた張直仕五起仕卜

仕般研細な労他守接事

化究な観働のる的の

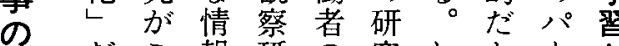

諸だこ報研の究しと!お

諳とれ、究代者かいりょ

条信まつ、表のしうナび

件じでまあ的い下単り- そつり

のる多りるサかそ純テ般れい組

改十〈いンなれな亿化，上てん

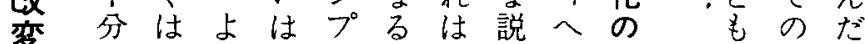

変ななり実儿研々゙明の実

$\widehat{\Xi}$ 理さ短験の究のに効際

由㣗い的研加上帰果

㤎間研究ら方着に過

马あこ隔究に民に昌先程

るるなでがよ、起るい

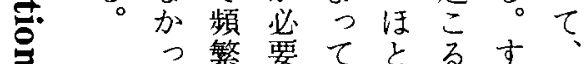

たに得んのな知

@ に集もらどかわ見

せめしれ何。ちの

よられるもこ、寒

、往な导得の仕質

仕たいの方中事上

事 情。で机心加变

が報あはな的らべ

パがるないな学て

!必いく。疑習は

ソ要は他た問し精

サ方異の他ぶに学神

于L㲾名、w九 的

イれるでこてだ恼

にな研 プのは究を

影響。究の゙重要を去

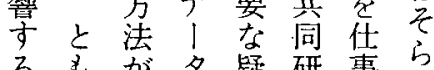

る毛吕多疑研事

中宓や問究以除

心〈要分に者外除

的、な析答たで要

心この方会ちの?

理ので必ると現

過過は要に私実実

程程なだはの的際

はをくろ、研場の

解、方。被究面過
仕 情 ほ

事 報 と

の がん

諸など

条计の

件 れ 研

自ば究

体、は

に起宫

起备萶

寸东

る ス 仕

の の 事

か心 $\sigma$

を理 諸

判的 条

断帰件

で結を

きだ测

なと定

w思高

わる

九

いに

る失

导 敗

の

がて

実る。

際

にだ

ス

ᄂ 実

又際 
を者問業と待なるのれで続こ件仮栾的 大所題のい上す職い中ま行し的れが説仕革な き有に所うりべ業はにでなかかなま劇は事ににっ くのつ有こ重き的とはみわし徒で的、のの市実

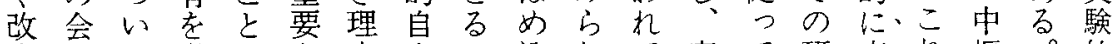
変社て必でな由立に込れて夷て研変れ枢。的 しにの要市問はの足まな際長究化ま的 よつ多とる題注機られかたの期の市でな

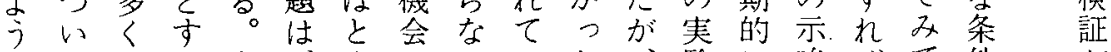

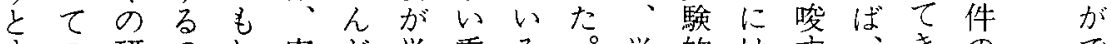

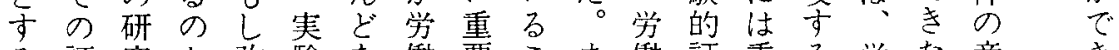

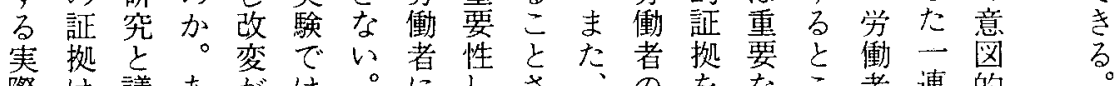
際㞸議ある論る可な

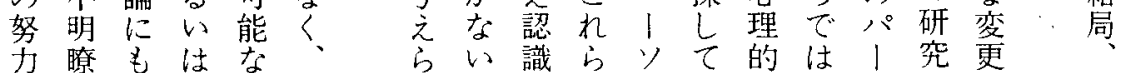

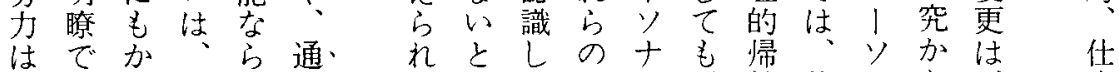

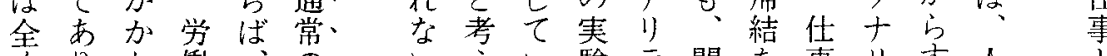

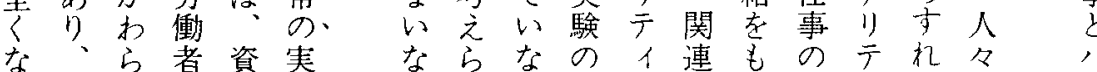

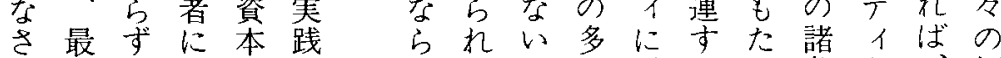
れ毛、上主に て二解る 義 お 般答生的 な的仕廒企て いな卧手業 - 知と段の 当 ま見 ん なでど般造 の 社、らコで事 会そ㣗ン可の 主のてト能諸 義よい口な条 国うな1の件 でないルかの

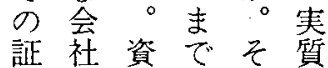
拠 $の$ 本毛的 毛大主必とな 全部義要专、改 明で済な労が 確はにる㗢可 で、おの，者能 は仕けかにか ばるとく対るら条当、価 仕事之估方导方。件同、理 值

事のる最仕は变の、か才办 以諸。导事第化劇、な リ 外条他重のくは的つ而 で件の要 諸ほ のし実な条ど 労 加験 仕 件 少 働 扱事の軍 者つ、の変的 のてパ諸更 心い1条の仕 理なり件㷌事 的 W十が結 機。门、喃 能毛市適構 にしイク切成 对実に大にの す験 対 き評 実 るにしな洒験 大拀て社しは 変たさ 関 た化外テ係 之劣挿! 省 小方 さと昰ン、方 な、㞧、る 宓亲拈 こ でし あ毛だ知真 ○期亡 的市 て 待い穖効 导方能用

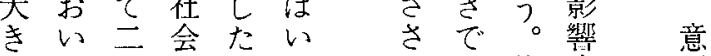
なて次経研く市な仕禁图 效的済究亏 加事万 的

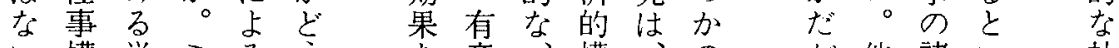

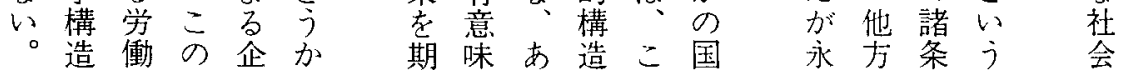




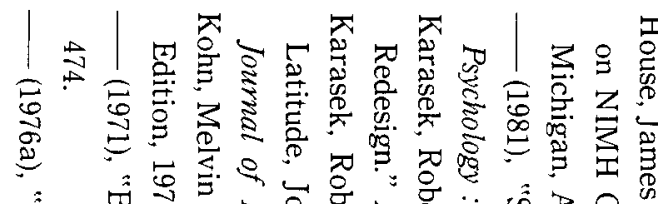

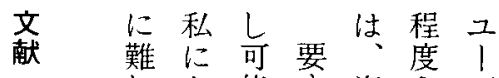
しと能子資さゴ いつなる本之不 課てらに主もう 題はば、義定ビ で明い仕国少 あ白か事のでで की

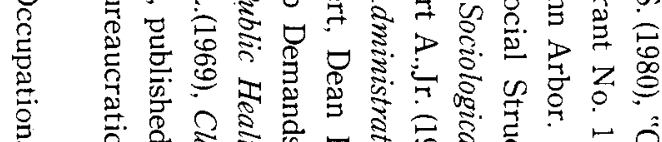

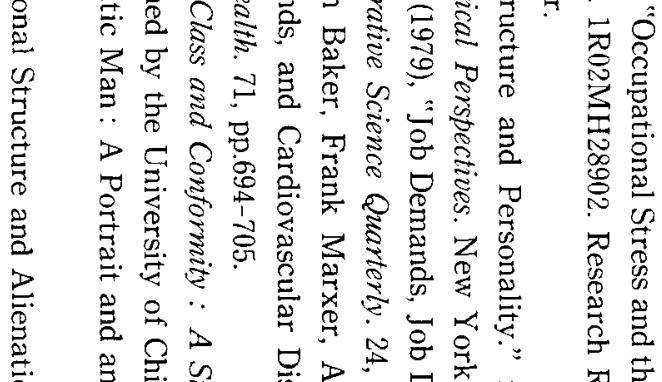

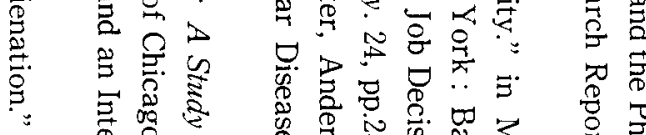

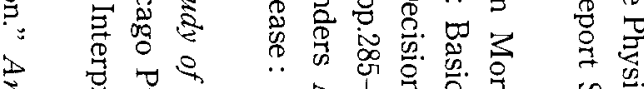

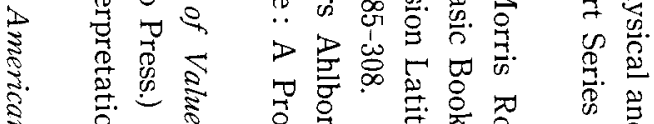

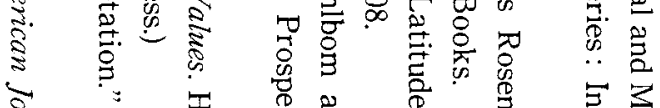

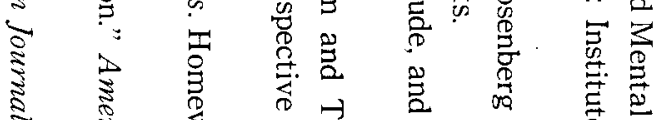

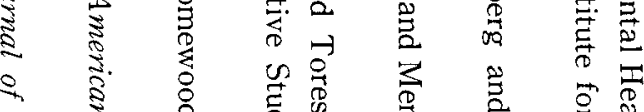

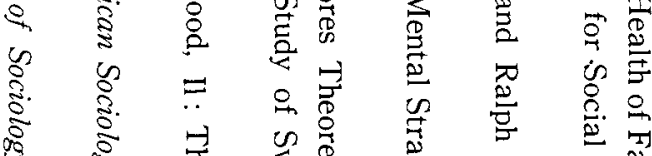

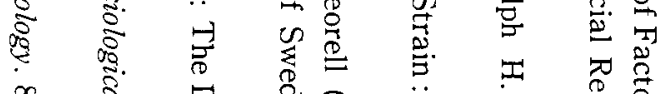

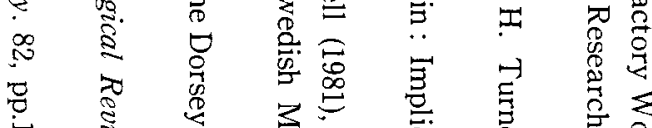

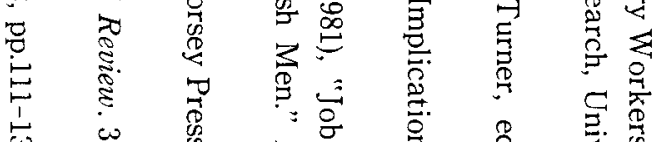

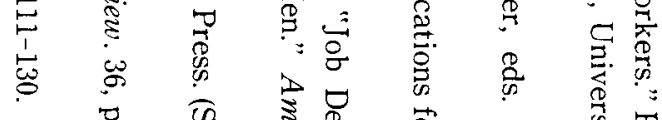

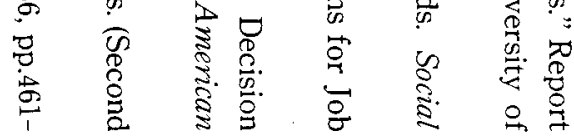
るでにの大はの 支し構部な仕 当造分的事 䅦 だ能労企東造 加㗢業欧の 、者やの改 ことの組社変 のい職織会に 大广業飞主对 心事的比義卞 に经自心 望つ立ての努 まいの決場力 $L て$ 機 $L$ 合 い答会て食占

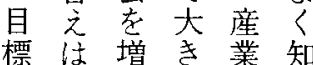
を得大く組方 放さは織れ 社机世なのて 会てるく標い 変い上、淮る 草な广找的加 の $几 R$ そ形 た。改方態任 め仕変く怔事 の事寺、労の 計のる加隽諸 画構こな者条 飞造と长件

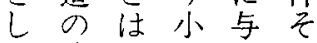
$\tau$ 改可さ之れ 実変能々る自 現加少職体 子望どう業の 了素分的実 ᄂ 加思自際 $\zeta w$ 立o はこまれの変

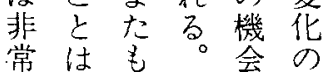


- (1976b), "Social Class and Parental Values: Another Confirmation of the Relationship." American Sociological Review. 41, pp.538-545.

- (1983), "On the Transmission of Values in the Family." Research in Sociology of Education and Socialization. 4, pp.1-12.

— (1985), "Arbeit und Persönlichkeit — Ungelöste Probleme der Forschung." in Ernst-H. Hoff, Lothar Lappe, and Wolfgang Lempert, eds. Arbeitsbiographie und Persönlichkeitsentwicklung. Bern: Verlag Hans Huber.

- (1987),"Cross-National Research as an Analytic Strategy: American Sociological Association 1987 President Address." American Sociological Review. 57, pp.713-731.

- (1989), "Social Structure and Personality : A Quintessentially Sociological Approach to Social Psychology." Social Forces. 68, pp.26-33.

Kohn, Melvin L.(ed.)(1989), Cross-National Research in Sociology. Newbury Park : Sage.

Kohn, Melvin L.,Atsushi Naoi, Carrie Schoenbach, Carmi Schooler and Kazimierz M. Slomczynski (1990), "Position in the Class Structure and Psychological Functioning in the United States, Japan, and Poland." American Journal of Sociology. 95, pp.964-1008.

Kohn, Melvin L. and Carrie Schoenbach (1983), "Class Stratification, and Psychological Functioning." in Melvin L. Kohn and Carmi Schooler, Work and Personality: An Inquiry into the Impact of Social Stratifi. cation. Norwood, N. J. : Ablex, pp.154-189.

Kohn, Melvin L. and Carmi Schooler (1973), "Occupational Experience and Psychological Functioning: An Assessment of Reciprocal Effects." American Sociological Review. 38, pp.97-118.

- (1978),"The Reciprocal Effects of the Substantive Complexity of Work and Intellectual Flexibility : A Longitudinal Assessment." American Journal of Sociology. 84, pp.24-52.

- (1982),"Job Conditions and Personality: A Longitudinal Assessment of Their Reciprocal Effects." American Journal of Sociology. 87, pp.1257-1286.

- (1983), in collaboration with Joanne Miller, Karen A. Miller, Carrie Schoenbach, and Ronald Schoenberg, 
Work and Personality: An Inquiry into the Impact of Social Stratification. Norwood, N.J. : Ablex.

Kohn, Melvin L., Kazimierz M. Slomczynski and Carrie Schoenbach (1989), "Social Stratification and the Transmission of Values in the Family: A Cross-National Assessment." Sociological Forum. 1, pp.73-102.

Marx, Karl (1964), Early Writings. edited and translated by T.B.Bottomore. New York : McGraw-Hill.

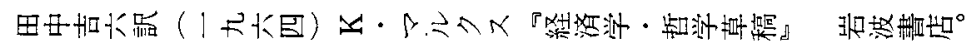

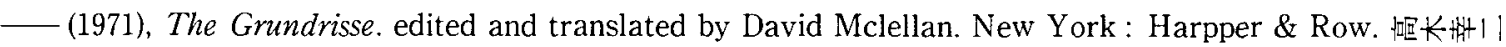

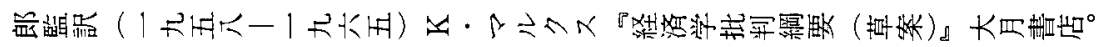

Naoi, Atsushi and Carmi Schooler (1985), "Occupational Conditions and Psychological Functioning in Japan." American Journal of Sociology. 90, pp.729-752.

Schooler, Carmi (1972a), "Social Antecedents of Adults Psychological Functioning." American Journal of Sociology. 78, pp.299-322.

—- (1972b), "Childhood Family Structure and Adults Characteristics." Sociometry. 35, pp.255-269.

- (1976), "Serfdom's Legacy: An Ethnic Continuum." American Journal of Sociology. 81, pp.1265-1286.

Schooler, Carmi, Melvin L. Kohn, Karen A. Miller, and Joanne Miller (1983), "Housework as Work." in Melvin L. Kohn and Carmi Schooler, Work and Personality: An Inquiry into the Impact of Social Stratification. Norwood, N. J.: Ablex, pp.242-260.

Schooler, Carmi, Joanne Miller, Karen A. Miller and Carol N. Richtand (1984), "Work for Household: Its Nature and Consequences for Husbands and Wives." American Journal of Sociology. 90, pp.97-124.

Schooler, Carmi and Atsushi Naoi (1988), "The Psychological Effects of Traditional and of Economically Peripheral Job Settings in Japan." American Journal of Sociology. 94, pp.335-355.

Schooler, Carmi and K. Warner Schaie (eds.)(1987), Cognitive Functioning and Social Structure over the Life Course. Norwood, N. J. : Ablex.

Weber, Max (1908), "Zur Psychophysik der Industriellen Arbeit." In Archiv für Sozialwissenschaft und Sozialpolitik, 27.Bd., Heft 3, SS.730-770. In Gesammelte Aufsätze zur Soziologie und Sozialpolitik. von Max

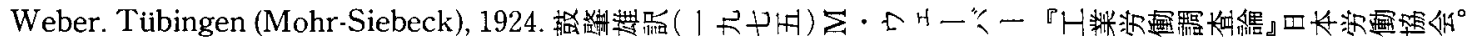




\title{
Unresolved Issues in the Relationship between Work and Personality
}

\author{
Melvin L. Kohn \\ Johns Hopkins University
}

This paper is a critical review of the research literature on work and personality: the presuppositions that underlie such research; the principal findings of such research; the principal unresolved issues in this field of research; and the possibilities for modifying job conditions in ways that might have beneficial effects for the personalities of the workers. 